\title{
KESIAPAN BERWIRAUSAHA SISWA SMK DI DAERAH ISTIMEWA YOGYAKARTA
}

\author{
Dwi Rahdiyanta \\ Jurusan Pendidikan Teknik Mesin FT UNY \\ Email: dwi_rahdiyanta@uny.ac.id
}

\begin{abstract}
The purpose of this study is to determine the effect of family environment factors, industry practice experience, and entrepreneurial knowledge on Vocational High Schools (VHSs) students' entrepreneurship readiness in Yogyakarta. From a total population of 1095 students,300 were selected as samples using the proportional random sampling technique by means of the Krejcie and Morgan formula. The data were collected through inventories, observation sheets, and documents. The content validity was assessed through expert judgment. The construct validity was assessed using the factor analysis and the reliability using the Cronbach's Alpha formula. The data were analyzed using the descriptive analysis, regression analysis, and path analysis at a significance level of 0.05 . The results show that: (1) there is a positive and significant influence of family environment, industry practice experience, and entrepreneurial knowledge on VHSs students' entrepreneurial readiness; and (2) family environment factors, industry practice experience, and entrepreneurial knowledge have a significant influence both directly and indirectly in determining the entrepreneurship readiness of VHSs students.
\end{abstract}

Keywords: entrepreneurship readiness, industrial work practices, mechanical engineering

\begin{abstract}
ABSTRAK
Tujuan penelitian ini adalah untuk mengetahui pengaruh faktor lingkungan keluarga, pengalaman praktik industri, dan pengetahuan kewirausahaan terhadap kesiapan berwirausaha siswa SMK di DIY. Penelitian ini merupakan penelitian korelasional yang bersifat ex-post facto. Populasi penelitian berjumlah 1095 orang siswa. Jumlah sampel penelitian pada taraf kesalahan 5\% sebanyak 300 siswa ditentukan dengan formula Krejcie dan Morgan. Pengambilan sampel dilakukan dengan teknik proportional random sampling. Data dikumpulkan dengan inventori, lembar pengamatan dan dokumentasi. Hasil penelitian menunjukkan bahwa terdapat pengaruh yang positif dan signifikan lingkungan keluarga, pengalaman praktik industri, dan pengetahuan kewirausahaan terhadap kesiapan berwirausaha siswa SMK. Disamping itu, faktor lingkungan keluarga, pengalaman praktik industri, dan pengetahuan kewirausahaan memiliki pengaruh yang signifikan baik secara langsung maupun tidak langsung dalam menentukan kesiapan berwirausaha siswa SMK.
\end{abstract}

Kata kunci: kesiapan berwirausaha, praktik kerja industri, teknik mesin

\section{PENDAHULUAN}

Masalah tenaga kerja pada saat ini menjadi masalah yang sangat krusial di Indonesia. Secara nasional pengangguran di Indonesia masih tergolong tinggi. Penyerapan tenaga kerja masih didominasi oleh pekerja berpendidikan rendah yaitu sekolah dasar ke bawah sebesar 55,51 juta orang atau 49,21 persen. Dari data tersebut untuk lulusan Sekolah Menengah Kejuruan (SMK) yang belum terserap di dunia kerja sebesar 9,43 juta orang (BPS, 2011).

Yogyakarta sebagai kota pendidikan masih menghadapi masalah pengangguran. Menurut data dari Departemen Tenaga Kerja dan Transmigrasi Daerah Istimewa Yogyakarta seperti yang dirilis pada situs 
http://www.nakertrans. jogjaprov.go.id, tanggal 21 Juni 2012, menyatakan bahwa angka pencari kerja yang belum ditempatkan sebanyak 56.489 orang yang tersebar di 5 kabupaten/kota dengan rincian Kota Yogyakarta sebanyak 8.437 orang, Kabupaten Bantul sebanyak 7.706 orang, Kabupaten Sleman sebanyak 30.683 orang, Kabupaten Kulon Progo sebanyak 7.580 orang, dan Kabupaten Gunungkidul sebanyak 8.905 orang. Adapun lowongan kerja yang tersedia hanya sebanyak 24.208 orang. Dari angka tersebut menunjukkan tidak seimbangnya kebutuhan tenaga kerja dengan jumlah pencari kerja itu sendiri. Lulusan SMK perlu dibekali dengan kesiapan kerja sesuai dengan bidang keahliannya juga perlu dibekali dengan kemampuan untuk berwirausaha. Dengan memiliki kesiapan untuk berwirausaha diharapkan lulusan SMK dapat menciptakan lapangan kerja sendiri sehingga tidak tergantung sepenuhnya pada lapangan kerja yang disediakan oleh industri atau dunia kerja.

Pemerintah melalui Kementerian Pendidikan Nasional telah memasukan kurikulum mata pelajaran kewirausahaan pada tingkat sekolah menengah kejuruan. Tujuan mata pelajaran kewirausahaan adalah memahami dunia usaha dalam kehidupan sehari-hari, berwirausaha dalam bidangnya serta mengaktualisasikan sikap dan perilaku berwirausaha (Akhmad Sudrajat, 2008: 38). Dari pendidikan kewirausahaan, siswa dibekali bagaimana mengelola sebuah usaha sejak bagaimana berkomunikasi dengan pelanggan, mengelola keuangan hingga mengelola informasi untuk mengambil keputusan.

Perilaku kewirausahaan tidak harus dimiliki oleh orang-orang yang telah bekerja atau mempunyai usaha, akan tetapi perlu disiapkan mulai dari pendidikan termasuk pendidikan di SMK. Pada dasarnya manusia mempunyai jiwa yang kreatif dan inovatif dalam kehidupannya. Melalui belajar kewirausahaan siswa diharapkan mampu mengubah pola pikir dari mencari pekerjaan menjadi menciptakan pekerjaan. Agar penanaman jiwa kewirausahaan siswa SMK dapat berhasil dengan baik, maka perlu dibangun jaringan kerjasama yang efektif dan efisien antara sekolah, keluarga, masyarakat industri dan dunia ekonomi pada umumnya. Kerja sama sebagai pilar utama dalam pelaksanaan Pendidikan Sistem Ganda yang tertuang dalam program praktik kerja industri (prakerin) perlu terus ditingkatkan dan disempurnakan.

Praktik Kerja Industri atau sering disebut dengan istilah Work-based Learning (WBL) adalah pendekatan pembelajaran yang memanfaatkan tempat kerja untuk menstrukturkan pengalaman-pengalaman yang diperoleh di tempat kerja berkontribusi pada sosial, akademik, dan pengembangan karir peserta didik. Pengalaman belajar di tempat kerja diaplikasikan, didalami, serta diperluas dalam pembelajaran baik di sekolah atau kampus maupun di tempat kerja. Dengan WBL, peserta didik dapat mengembangkan sikap (attitude), pengetahuan (knowledge), keterampilan (skill), pencerahan (insight), perilaku (behavior), kebiasaan (habits), dan pergaulan (associations) yang terkait dengan aktivitas bekerja nyata (real-life work activities) (Lynch \& Harnish, 1998). Berbagai bentuk/model WBL antara lain: apprenticeship opportunities, career mentorship, cooperative work experience, credit for prior learning (CPL), internship, job shadowing, practicum, school-based enterpreunership, service learning, teacher externship, tech-prep, vocational student organizations, volunteer service, and worksite field trip (WBL Guide,2002).

Pada pendidikan kejuruan, model $W B L$ sangat tepat diterapkan pada mata pelajaran praktik. Hal ini sangat beralasan, karena mata pelajaran praktik merupakan mata pelajaran utama dan menjadi ciri khas dari pendidikan kejuruan. Pengembangan pembelajaran praktik pada pendidikan kejuruan harus terus dilakukan agar kualitas lulusannya sesuai dengan tuntutan dunia kerja. Oleh karena itu maka pendidikan kejuruan harus dapat menjalin bekerjasama 
yang baik dengan dunia usaha dan dunia industri.

Praktik kerja industri merupakan proses pembelajaran di tempat kerja. Kegiatan ini mendorong siswa untuk belajar dan bekerja secara nyata dalam kegiatan usaha atau bisnis wirausaha dengan perusahaan tertentu pada bidang tertentu pula. Dengan melaksanakan Praktik Kerja Industri diharapkan siswa memiliki pemahaman dasar pada bidang-bidang yang dipelajari dengan standar-standar kerja yang telah ditetapkan. Kegiatan praktikkerja industri diharapkan dapat memotivasi siswa untuk mengembangkan ide dan menciptakan peluang untuk berwirausaha.

Rendahnya jenjang pendidikan, tidak seimbangnya antara jumlah pencari kerja dan lowongan pekerjaan, minimnya keterampilan yang dimiliki dalam bekerja dan minimnya informasi untuk mendapatkan pekerjaan masih menjadi beberapa penyebab tingginya angka pengangguran di Indonesia. Dari hasil penelusuran lulusan yang dilakukan pada tiga Sekolah Menengah Kejuruan (SMK) di Gunungkidul pada tahun 2012, yaitu lulusan SMKN 1 Tanjungsari, SMKN 2 Wonosari dan SMKN 1 Nglipar, yang berjumlah 141 orang lulusan diperoleh data sebagai berikut: 1) prosentase lulusan yang bekerja tidak sesuai dengan kompetensinya sejumlah 71 orang dari 141 siswa atau 50,6\%; 2) yang bekerja sesuai dengan kompetensinya sejumlah 15 orang dari 141 lulusan atau $11,2 \%, 3$ ) lulusan yang belum bekerja sejumlah 25 orang dari 141 atau 18,3\%; dan 4) lulusan yang melanjutkan studi sebanyak 28 orang atau 19,7\% (Sri Suprobo, 2013). Berdasarkan hasil penelusuran ini dapat disimpulkan bahwa lulusan SMK belum terserap secara signifikan sesuai dengan kompetensinya.

Tujuan penelitian ini adalah untuk mengetahui gambaran mengenai lingkungan keluarga siswa, pengalaman prakerin, pengetahuan kewirausahaan, dan kesiapan berwirausaha siswa SMK pada Kompetensi Keahlian Teknik Mesin. Selain itu, penelitian ini akan mengetahui pengaruh faktor lingkungan keluarga, pengalaman prakerin, dan pengetahuan kewirausahaan terhadap kesiapan berwirausaha siswa SMK pada Kompetensi Keahlian Teknik Mesin di Daerah Istimewa Yogyakarta.

\section{METODE}

Penelitian ini merupakan penelitian korelasional dengan tujuan untuk merumuskan faktor-faktor yang berpengaruh terhadap kesiapan berwirausaha siswa SMK Program Keahlian Teknik Mesin di DIY.

Populasi dalam penelitian ini adalah siswa SMK kelas XII yang telah melaksanakan praktik kerja industri (Prakerin) pada Program Keahlian Teknik Pemesinan di Daerah Istimewa Yogyakarta yang berjumlah 1095 orang siswa. Jumlah sampel ditentukan menurut Krejcie dan Morgan (Issac, 1981: 192) dengan menggunakan taraf kesalahan 5\%. Berdasarkan hasil perhitungan, diperoleh ukuran sampel sebesar 285 responden (pembulatan). Untuk mengantisipasi angket maupun data yang tidak dapat terolah, jumlah sampel ditambah sebesar 5\%. Dengan demikian sampel minimal yang digunakan dalam penelitian ini adalah sebesar: $285+(5 \%$ x 285 $)=300$ responden (pembulatan $)$. Teknik sampling yang digunakan adalah proportional random sampling sehingga jumlah sampel kelompok dihitung berdasarkan jumlah populasi masing-masing kelompok (sekolah).

Teknik pengumpulan data dalam penelitian ini adalah survey dengan menggunakan alat pengumpul data berupa angket, lembar pengamatan, dan dokumentasi. Validitas instrumen dalam penelitian ini meliputi validitas isi (content validity) dan validitas konstruk (construct validity). Untuk mengetahui validitas isi instrumen dilakukan melalui expert judgement dengan teknik Delphi. Pengujian validitas konstruk menggunakan analisis faktor konfirmatori untuk mengetahui apakah butirbutir instrumen tersebut cocok untuk menaksir unsur-unsur yang terdapat dalam konstruk yang telah ditetapkan (Ary, Jacobs Razavieh, 
1982:289-291; Coakes \& Stead, 1996:123). Perhitungan reliabilitas instrumen penelitian menggunakan kaidah Cronbach Alpha (Fernandes, 1984:61). Hasil uji reliabilitas instrumen untuk lingkungan keluarga sebesar 0,88; pengalaman praktek kerja industri (Prakerin) sebesar 0,79; pengetahuan kewirausahaan sebesar 0,91; dan kesiapan berwirausaha siswa SMK sebesar 0,93. Dengan demikian berarti instrumen penelitian yang telah disusun dapat digunakan untuk pengumpulan data penelitian.
Teknik analisis data dalam penelitian ini meliputi dua analisis yaitu analisis deskriptif dan analisis inferensial (uji hipotesis) yang meliputi analisis korelasi, regresi dan analisis jalur, dengan terlebih dahulu dilakukan uji persyaratan analisis (normalitas, linieritas, homoskedas-tisitas, dan multikolinieritas).

Adapun tata hubung antar variabel dalam penelitian ini ditampilkan pada Gambar 1.

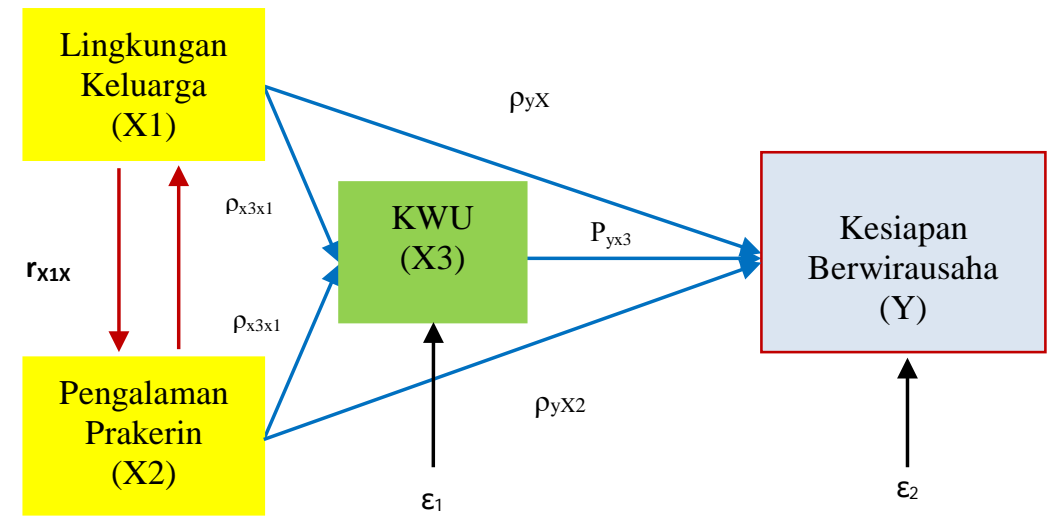

Gambar 1. Tatahubung Antar Variabel

\section{HASIL DAN PEMBAHASAN}

Deskripsi data dalam penelitian ini meliputi penyajian ukuran distribusi frekuensi, ukuran tendensi sentral (mean, modus, median), ukuran penyebaran (simpangan baku), dan interpretasi deskriptif dari variabel lingkungan keluarga (X1), pengalaman prakerin (X2), pengetahuan kewirausahaan (X3), dan kesiapan berwirausaha (Y). Rangkuman hasil analisis disajikan dalam Tabel 1.

Tabel 1. Ringkasan Hasil Analisis Deskriptif

\begin{tabular}{ccccccccc}
\hline Var. & SD. & Mi & M & Me & Mo & M : Mi & $\begin{array}{c}\text { Pencapaian } \\
\text { Skor (\%) }\end{array}$ & Kategori \\
\hline $\mathrm{X} 1$ & 9,67 & 78 & 95,66 & 95,00 & 96,00 & Lebih besar & 73,5 & Tinggi \\
\hline $\mathrm{X} 2$ & 5,41 & 33 & 44,03 & 44,00 & 44,00 & Lebih besar & 80,3 & Tinggi \\
\hline $\mathrm{X} 3$ & 7,16 & 54 & 75,29 & 75,00 & 72,00 & Lebih besar & 83,6 & Tinggi \\
\hline $\mathrm{Y}$ & 6,92 & 51 & 69,22 & 69,00 & 70,00 & Lebih besar & 81,0 & Tinggi \\
\hline
\end{tabular}

Berdasarkan hasil analisis deskriptif dapat diketahui bahwa skor rata-rata empiris (M) > skor rata-rata kriteria (Mi). Dari Tabel 1 di atas juga dapat diketahui bahwa pencapaian skor untuk semua variabel penelitian di atas $70 \%$. Dengan demikian dapat disimpulkan bahwa seluruh variabel dalam penelitian ini secara umum termasuk dalam kategori tinggi.

Korelasi atau hubungan antar masingmasing variabel penelitian dapat diketahui dengan menguji hipotesis: Ada hubungan yang signifikan antar masing-masing variabel penelitian yaitu: lingkungan keluarga $\left(\mathrm{X}_{1}\right)$, pengalaman praktik industri $\left(\mathrm{X}_{2}\right)$, pengetahuan kewirausahaan $\left(\mathrm{X}_{3}\right)$, dan kesiapan berwirausaha $(\mathrm{Y})$. Untuk menguji hipotesis ini digunakan analisis korelasi jenjang nihil antara masingmasing variabel penelitian dengan product moment dari Pearson. Berdasarkan hasil analisis korelasi antar masing-masing variabel 
penelitian sebagaimana dapat dilihat pada Tabel 2, dapat disimpulkan bahwa hipotesis yang menyatakan terdapat hubungan yang positif dan signifikan antara masing-masing variabel penelitian diterima dan teruji kebenarannya pada taraf signifikansi 0,05. Rangkuman hasil analisis korelasi antar masing-masing variabel penelitian tersaji pada Tabel 2.

Tabel 2. Rangkuman Analisis Korelasi Jenjang Nihil Antar Variabel Penelitian

\begin{tabular}{rlrrrr}
\hline & & X1 & X2 & X3 & \multicolumn{1}{c}{ Y } \\
\hline \multirow{2}{*}{ X1 } & Pearson Correlation & 1 & .582 & .448 & .545 \\
\cline { 2 - 6 } & Sig. & .000 & .000 & .000 & .000 \\
\hline \multirow{2}{*}{ X2 } & Pearson Correlation & .582 & 1 & .535 & .515 \\
\cline { 2 - 6 } & Sig. & .000 & .000 & .000 & .000 \\
\hline \multirow{2}{*}{ X3 } & Pearson Correlation & .448 & .535 & 1 & .651 \\
\cline { 2 - 6 } & Sig. & .000 & .000 & .000 & .000 \\
\hline \multirow{2}{*}{$\mathrm{Y}$} & Pearson Correlation & .545 & .515 & .651 & 1 \\
\cline { 2 - 6 } & Sig. & .000 & .000 & .000 & .000 \\
\hline
\end{tabular}

Pengaruh lingkungan keluarga, dan pengalaman praktik kerja industri terhadap pengetahuan kewirausahaan dapat diketahui dengan menguji hipotesis: Ada pengaruh signifikan lingkungan keluarga $\left(\mathrm{X}_{1}\right)$, pengalaman praktik industri $\left(\mathrm{X}_{2}\right)$ pengetahuan kewirausahaan siswa SMK $\left(\mathrm{X}_{3}\right)$. Untuk menguji hipotesis ini digunakan analisis regresi ganda dengan menempatkan $X_{3}$ sebagai variabel terikat dan $\mathrm{X}_{1}$ dan $\mathrm{X}_{2}$ sebagai variabel bebas. Rangkuman hasil analisis tersaji dalam Tabel 3.

Tabel 3. Rangkuman hasil Analisis Regresi Ganda

\begin{tabular}{|c|c|c|c|c|c|c|c|}
\hline \multicolumn{2}{|c|}{ Variabel } & \multirow[b]{2}{*}{ B } & \multirow[b]{2}{*}{ Beta } & \multirow[b]{2}{*}{$\mathrm{r}_{\mathrm{par}}$} & \multirow{2}{*}{$\begin{array}{c}\text { Det. } \\
\text { Parsial } \\
\left(\mathrm{r}^{2} \text { par }\right)\end{array}$} & \multirow[b]{2}{*}{ thitung } & \multirow[b]{2}{*}{ Sig. $t$} \\
\hline Terikat & Bebas & & & & & & \\
\hline X3 & $\mathrm{X} 1$ & 0,225 & 0,305 & 0.267 & 0.071 & 4,743 & 0,000 \\
\hline $\begin{array}{l}R=0,695 \\
R^{2}=0,483 \\
F=55,000 \\
P<0,05 \\
C=25,13\end{array}$ & $\mathrm{X} 2$ & 0,572 & 0,433 & 0.423 & 0.179 & 4,994 & 0,000 \\
\hline
\end{tabular}

Hasil analisis regresi ganda berdasarkan Tabel 3 di atas menunjukkan bahwa $\mathrm{F}_{\text {hitung }}=$ 55,00 dan $\mathrm{p}<0.05$; dengan demikian berarti harga korelasi $(\mathrm{R})=0,695$ adalah signifikan pada taraf signifikansi 0,05. Berdasarkan hasil analisis tersebut maka hipotesis yang menyatakan: Ada pengaruh signifikan lingkungan keluarga $\left(\mathrm{X}_{1}\right)$, dan pengalaman praktik kerja industri siswa $\left(\mathrm{X}_{2}\right)$ terhadap pengetahuan kewirausahaan $\left(\mathrm{X}_{3}\right)$ diterima. Koefisien determinasi $\left(\mathrm{R}^{2}\right)=0,483$ menunjukkan sumbangan dua variabel tersebut sebesar $48,3 \%$.
Selanjutnya adalah mengungkap pengaruh lingkungan keluarga (X1), pengalaman praktik kerja industri (X2), dan pengetahuan kewirausahaan (X3) terhadap kesiapan berwirausaha siswa smk (Y) (determinasi kesiapan berwirausaha siswa SMK). Hipotesis yang diuji: Ada pengaruh signifikan lingkungan keluarga $\left(\mathrm{X}_{1}\right)$, pengalaman prakerin $\left(\mathrm{X}_{2}\right)$, pengetahuan kewirausahaan $\left(\mathrm{X}_{3}\right)$ terhadap kesiapan berwirausaha siswa SMK (Y). Untuk menguji hipotesis ini digunakan analisis regresi ganda dengan menempatkan $\mathrm{Y}$ sebagai variabel terikat dan $\mathrm{X}_{1}, \mathrm{X}_{2}$, dan $\mathrm{X}_{3}$ sebagai variabel bebas. Rangkuman hasil analisis regresi ganda tersaji pada Tabel 4. 
Tabel 4. Rangkuman hasil Analisis Regresi Ganda

\begin{tabular}{|c|c|c|c|c|c|c|c|}
\hline \multicolumn{2}{|c|}{ Variabel } & \multirow[b]{2}{*}{ B } & \multirow[b]{2}{*}{ Beta } & \multirow[b]{2}{*}{ rpar } & \multirow{2}{*}{$\begin{array}{c}\text { Det. } \\
\text { Parsial } \\
\left(\mathrm{r}^{2} \text { par }\right) \\
\end{array}$} & \multirow[b]{2}{*}{ thitung } & \multirow[b]{2}{*}{ Sig. $\mathrm{t}$} \\
\hline Terikat & Bebas & & & & & & \\
\hline $\mathrm{Y}$ & $X_{1}$ & 0,019 & 0,057 & 0.075 & 0.006 & 0,722 & 0,026 \\
\hline $\mathrm{R}=0,733$ & $\mathrm{X}_{2}$ & 0,284 & 0,222 & 0.223 & 0.050 & 3,992 & 0,000 \\
\hline $\begin{array}{l}\mathrm{R}^{2}=0,538 \\
\mathrm{~F}=56,816 \\
\mathrm{P}<0,05 \\
\mathrm{C}=12,199\end{array}$ & $\mathrm{X}_{3}$ & 0,366 & 0,378 & 0.371 & 0.138 & 6,844 & 0,000 \\
\hline
\end{tabular}

Hasil analisis regresi ganda berdasarkan Tabel 4 di atas menunjukkan bahwa $\mathrm{F}_{\text {hitung }}=$ 56,815) dan $\mathrm{p}<0,05$; dengan demikian berarti harga korelasi $(\mathrm{R})=0,538$ adalah signifikan pada taraf signifikansi 0,05. Berdasarkan hasil analisis tersebut maka hipotesis yang menyatakan: Ada pengaruh signifikan lingkungan keluarga $\left(\mathrm{X}_{1}\right)$, pengalaman prakerin $\left(\mathrm{X}_{2}\right)$, pengetahuan kewirausahaan $\left(\mathrm{X}_{3}\right)$ terhadap kesiapan berwirausaha siswa SMK (Y): diterima. Koefisien determinasi $\left(\mathrm{R}^{2}\right)=0,538$ menunjukkan sumbangan tiga variabel tersebut sebesar 53,8\%.

Secara individu lingkungan keluarga $\left(\mathrm{X}_{1}\right)$ memiliki pengaruh yang signifikan terhadap kesiapan berwirausaha siswa SMK $(\beta=0,057$ : $\mathrm{p}>0,05)$, pengalaman prakerin $\left(X_{2}\right)$ memiliki pengaruh signifikan kesiapan berwirausaha siswa SMK $(\beta=0,222: \quad p<0,05), \quad$ dan pengetahuan kewirausahaan siswa (X3) memiliki pengaruh signifikan terhadap kesiapan berwirausaha siswa SMK $(\beta=0,378$ : $p<0,05)$. Berdasarkan koefisien determinasi parsialnya, pengetahuan kewirausahaan mempunyai sumbangan terbesar terhadap kesiapan berwirausaha siswa SMK (13,8\%), pengalaman prakerin (5\%), dan lingkungan keluarga (0,6\%). Dengan demikian pengetahuan kewirausahaan memiliki pengaruh yang lebih dominan dalam menentukan kesiapan berwirausaha siswa SMK.

Berdasarkan harga prediktor dan konstanta hasil regresi ganda, dapat disusun persamaan regresi ganda sebagai berikut: $\mathrm{Y}=12,199+$ $0,019 X_{1}+0,284 X_{2}+0,366 X_{3}$. Dari hasil persamaan regresi tersebut dapat diketahui bahwa rata-rata skor kesiapan berwirausaha siswa SMK akan meningkat atau menurun masing-masing sebesar $(0,019),(0,284)$ dan $(0,366)$ untuk kenaikan/penurunan lingkungan keluarga, pengalaman prakerin, dan pengetahuan kewirausahaan siswa SMK sebesar satu unit.

Model hubungan kausal empirik yang memuat bobot regresi $(\beta)$ atau koefisien jalur disajikan pada Gambar 2.

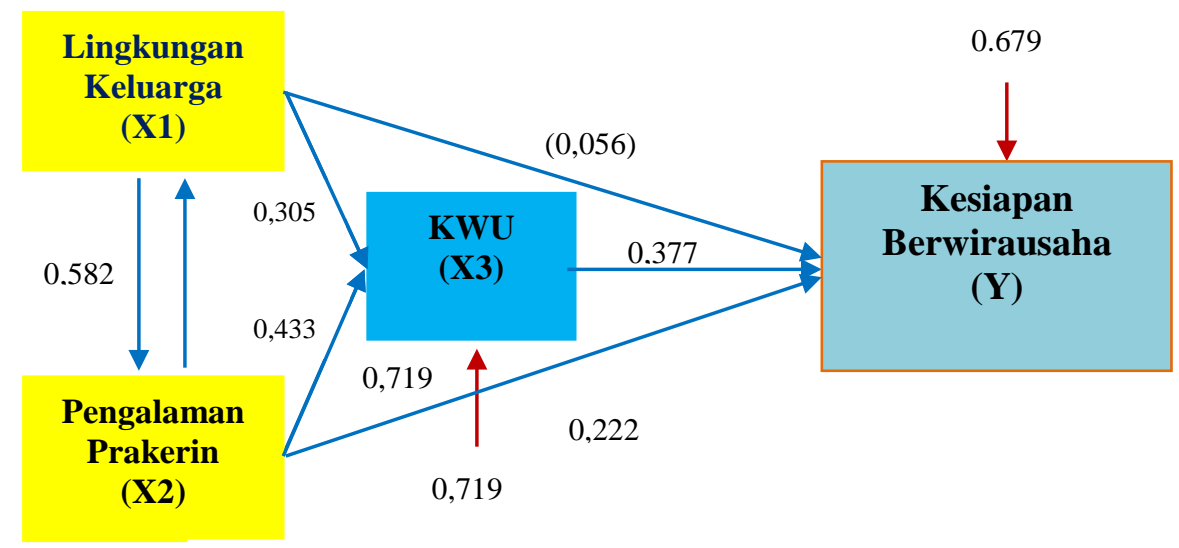

Gambar 2. Model Hubungan Kausal Empirik 
Untuk menguji pengaruh langsung dan tidak langsung dilakukan dengan menguji signifikansi koefisien jalur berdasarkan model hubungan kausal empirik. Harga koefisien jalur di bawah 0,05 dinyatakan tidak signifikan dan dikeluarkan dari model hubungan kausal empirik. Besarnya pengaruh langsung dapat diketahui dari koefisien beta hasil dua analisis regresi dengan menggunakan metode stepwise yaitu: (1) regresi ganda variabel $\mathrm{X}_{3}$ atas variabel
$\mathrm{X}_{1}$, dan $\mathrm{X}_{2}$, dan (2) regresi ganda variabel $\mathrm{Y}$ atas variabel $X_{1}, X_{2}$, dan $X_{3}$. Sedangkan pengaruh tidak langsung dihitung secara manual berdasarkan besarnya koefisien jalur langsung sesuai model hubungan kausal.

Adapun rangkuman hasil perhitungan besarnya pengaruh langsung, pengaruh tidak langsung, pengaruh non kausal dari model hubungan kausal tersebut dapat dilihat pada Tabel 5.

Tabel 5. Rangkuman Hasil Analisis Jalur

\begin{tabular}{|c|c|c|c|c|c|c|}
\hline \multicolumn{2}{|c|}{ Variabel } & \multirow{2}{*}{$\begin{array}{c}\text { Efek } \\
\text { Langsung }\end{array}$} & \multirow{2}{*}{$\begin{array}{c}\text { Efek tak } \\
\text { Langsung } \\
\text { Melalui } \\
X_{3} \\
\end{array}$} & \multirow{2}{*}{$\begin{array}{l}\text { Efek } \\
\text { Total }\end{array}$} & \multirow{2}{*}{$\begin{array}{c}\text { Efek } \\
\text { Non- } \\
\text { Kausal }\end{array}$} & \multirow[b]{2}{*}{ Korelasi } \\
\hline Terikat & Bebas & & & & & \\
\hline \multirow{2}{*}{ X3 } & $\mathrm{X}_{1}$ & 0,305 & - & 0,305 & 0.124 & 0,448 \\
\hline & $\mathrm{X}_{2}$ & 0,433 & - & 0,433 & 0.206 & 0,535 \\
\hline \multirow{3}{*}{$\mathrm{Y}$} & $\mathrm{X}_{1}$ & 0,057 & 0,040 & 0,040 & 0.234 & 0,545 \\
\hline & $\mathrm{X}_{2}$ & 0,225 & 0,162 & 0,162 & 0.210 & 0,515 \\
\hline & $\mathrm{X}_{3}$ & 0,378 & - & 0,378 & 0.409 & 0,651 \\
\hline
\end{tabular}

Berdasarkan perhitungan besarnya pengaruh langsung dan tidak langsung dapat diketahui: (a) pengaruh langsung lingkungan keluarga terhadap kesiapan berwirausaha siswa SMK signifikan, demikian juga pengaruh tidak langsung melalui pengatahuan kewirausahaan signifikan; dan (b) pengaruh langsung pengalaman prakerin siswa kesiapan berwirausaha siswa SMK signifikan. Demikian juga pengaruh tidak langsung melalui pengetahuan kewirausahaan signifikan.

Berdasarkan hasil analisis jalur tersebut dapat disimpulkan bahwa lingkungan keluarga siswa, pengalaman prakerin, dan pengetahuan kewirausahaan memiliki peran yang sangat penting terhadap kesiapan berwirausaha siswa SMK.

Berdasarkan hasil analisis korelasi antar variabel penelitian, dapat diketahui bahwa hubungan antar variabel termasuk dalam kriteria cukup kuat. Adapun angka korelasi yang paling kecil terdapat pada hubungan antara lingkungan keluarga dengan pengetahuan kewirausahaan $(\mathrm{r}=0,448)$. Sedangkan angka korelasi yang paling besar terdapat pada hubungan antara pengetahuan kewirausahaan dengan kesiapan berwirausaha siswa SMK $(\mathrm{r}=0,651)$. Adanya korelasi yang kuat antara pengetahuan kewirausahaan dengan kesiapan berwirausaha siswa SMK, mengindikasikan bahwa pengetahuan kewirausahaan memiliki pengaruh yang kuat terhadap kesiapan berwirausaha siswa SMK. Hal ini sesuai dengan hasil penelitian Paul (2008) dan Cris Zirkle (2005) yang menemukan bahwa terdapat hubungan yang positif antara pengetahuan dan motivasi dengan kesiapan berwirausaha siswa SMK. Oleh sebab itu maka penguasaan pengetahuan kewirausahaan perlu dipertahankan dan ditingkatkan lagi dengan cara meningkatkan kualitas proses, out-put dan out-come di SMK.

Berdasarkan hasil analisis regresi ganda menunjukkan bahwa lingkungan keluarga, pengalaman prakerin dan pengetahuan kewirausahaan siswa SMK memiliki pengaruh yang positif dan signifikan terhadap kesiapan berwirausaha siswa SMK. Demikian juga ternyata secara sendiri-sendiri lingkungan keluarga, pengalaman prakerin dan pengetahuan 
kewirausahaan memiliki pengaruh yang signifikan terhadap kesiapan berwirausahan siswa SMK.

Ahmad Zahrowi (2007) menemukan bahwa penguasaan informasi tentang lapangan kerja memberikan sumbangan sebesar 74,4 \% terhadap pengetahuan kewirausahaan. Temuan tersebut di atas juga selaras dengan berbagai rumusan (Sumitro, dkk., 1998: 80; Syamsu Yusuf, 2001: 75; dan Mohammad Ali:141), yang menyatakan bahwa faktor penguasaan informasi, pemahaman diri dan sikap siswa yang pada prakerin merupakan faktor penentu pemilihan bidang dalam berwirausaha. Kurangnya wawasan terhadap dunia kerja juga dapat mempengaruhi dalam pemilihan jenis bidang usaha yang akan ditekuni dalam berwirausaha (Hurlock, 1980:166).

Hasil analisis jalur menunjukkan bahwa pengaruh langsung pengalaman prakerin terhadap kesiapan berwirausaha siswa SMK signifikan, demikian juga pengaruh tidak langsung melalui pengetahuan kewirausahaan signifikan. Hasil analisis jalur tersebut menunjukkan bahwa pengetahuan kewirausahaan mempunyai arti dalam menjelaskan pengaruh pengalaman prakerin terhadap kesiapan berwirausaha siswa SMK. Hasil ini selaras dengan hasil penelitian yang menyatakan bahwa penguasaan informasi tentang dunia kerja akan sangat berpengaruh pada persepsi dan sikap pada SMK yang yang pada gilirannnya akan sangat berpengaruh terhadap keakuratan dalam penentuan bidang keahlian atau pekerjaan yang akan ditekuni setelah lulus SMK (Ahmad Zahrowi, 2007; dan Hurlock, 1980:166). Dengan demikian berarti bahwa penguasan informasi merupakan salah faktor yang amat bermanfaat dalam pengambilan suatu keputusan. Jika dikaitkan dengan kesiapan berwirausaha siswa SMK, maka siswa yang memiliki penguasaan informasi yang baik tentu akan lebih memiliki pertimbangan-pertimbangan yang lebih baik dan akurat dalam memilih bidang pekerjaan yang akan ditekuninya setelah lulus dari SMK. Penguasaan informasi juga sangat dipengaruhi oleh faktor situasional baik dari aspek lingkungan sekolah, lingkungan keluarga dan lingkungan sosial masyarakat. Hal ini berarti jika faktor situasional tersebut baik, maka akan mendukung terjadinya proses penguasaan informasi yang baik pula yang pada gilirannya akan memberikan pada anak wawasan yang komprehensif berkaitan dengan citra SMK, perkembangan ilmu pengetahuan dan teknologi, serta dunia kerja.

Hasil analisis jalur juga menunjukkan bahwa pengaruh langsung lingkungan keluarga terhadap kesiapan berwirausaha siswa SMK signifikan, demikian juga pengaruh tidak langsung melalui pengetahuan kewirausahaan signifikan. Hasil analisis jalur tersebut menunjukkan bahwa pengetahuan tentang kewirausahaan dari siswa SMK mempunyai arti dalam menjelaskan pengaruh lingkungan keluarga terhadap kesiapan berwirausaha siswa SMK. Hasil temuan ini selaras dengan pendapat Mifflen dan Mifflen (1986: 65) yang menyatakan bahwa konsep diri atau pemahaman diri memegang peran yang sangat dominan dalam pembentukan kepribadian dan sikap anak. Dengan demikian berarti bahwa kemampuan memahami diri sendiri merupakan satu aktivitas psikologis yang penting dalam diri individu untuk melakukan sesuatu. Seseorang yang memiliki pemahaman atau pengetahuan yang baik akan berpengaruh terhadap orientasi pilihan pada bidang pekerjaan yang diidamkan oleh siswa. Hal ini sangat beralasan mengingat bahwa setiap bidang keahlian atau pekerjaan tentu memiliki karakteristik dan persyaratan yang diperlukan, serta akan memiliki dampak intrinsik dan ekstrinsik bila memiliki pekerjaan tersebut.

Hasil analisis jalur juga menunjukkan bahwa pengetahuan kewirausahaan memiliki pengaruh yang signifikan dan paling besar terhadap kesiapan berwirausaha siswa SMK. Dengan demikian hal ini selaras dengan pendapat Mohammad Ali dan Mohammad Asrori (2009:141), yang menyatakan bahwa pengetahuan yang dimiliki oleh seseorang akan akan banyak mewarnai perilaku atau sikap 
seseorang. Sikap merupakan kecenderungan untuk bereaksi terhadap orang, lembaga, atau peristiwa baik secara positif mapun negatif. Lebih lanjut disebutkan bahwa menurut teori determinisme, sikap manusia diturunkan atau dipengaruhi oleh determinisme genetis (genetic determinism), determinisme psikis (psychic determinism), dan determinisme lingkungan (environmental deteriminism). Determinisme genetis berpandangan bahwa sikap individu diturunkan oleh sikap kakek-neneknya. Determinisme psikis berpandangan bahwa sikap individu merupakan hasil dari perlakuan, pola asuh, atau pendidikan orang tua yang diberikan kepada anaknya. Determinisme lingkungan (environmental determism) berpandangan bahwa perkembangan sikap seseorang sangat dipengaruhi oleh lingkungan tempat individu tinggal dan bagaimana lingkungan memperlakukan individu tersebut. Demikian juga menurut Thomson (1973), bahwa pemilihan bidang pekerjaan seseorang dipengaruhi oleh aspek sosial dan psikologis. Dari uraian di atas dapat ditarik kesimpulan bahwa sikap seseorang disamping dipengaruhi faktor dari dalam yaitu pemahaman terhadap dirinya dan penguasaan informasi atau wawasan yang dimiliki, juga dipengaruhi oleh faktor dari luar yaitu lingkungan orang tua, lingkungan sekolah, dan lingkungan sosial masyarakat dimana mereka tinggal.

\section{SIMPULAN}

Hasil sajian data dan pembahasan menunjukkan bahwa: (a) Terdapat hubungan yang positif dan signifikan antara masing-masing variabel lingkungan keluarga, pengalaman prakerin, pengetahuan kewirausahaan, dan kesiapan berwirausaha siswa SMK. Hubungan antar variabel dalam penelitian ini termasuk dalam kriteria kuat. Adapun angka korelasi yang paling kecil terdapat pada hubungan antara lingkungan keluarga dengan pengetahuan kewirausahaan $(\mathrm{r}=0,448)$. Sedangkan angka korelasi yang paling besar terdapat pada hubungan antara pengetahuan kewirausahaan dengan kesiapan berwirausaha siswa SMK di SMK ( $\mathrm{r}=0,651)$. (b) Lingkungan keluarga, pengalaman prakerin, dan pengetahuan kewirausahaan memiliki pengaruh yang positif dan signifikan terhadap kesiapan berwirausaha siswa SMK dengan sumbangan sebesar 53,8\%. Berdasarkan koefisien determinasi parsialnya, pengetahuan kewirausahaan siswa mempunyai sumbangan terbesar terhadap kesiapan berwirausaha siswa SMK (13,8\%), diikuti secara berurutan pengalaman prakerin (5\%), dan lingkungan keluarga (4,6\%). Dengan demikian pengetahuan kewirausahaan memiliki pengaruh yang lebih dominan terhadap pembentukan kesiapan berwirausaha siswa SMK. (c) Lingkungan keluarga, pengalaman prakerin, dan pengetahuan kewirausahaan siswa memiliki pengaruh yang positif dan signifikan baik secara langsung maupun tidak langsung terhadap kesiapan berwirausaha siswa SMK.

\section{DAFTAR RUJUKAN}

Ary, Donald., Jacobs \& Razavieh. (1982). Introduction to research in education. New York: Holt, Rinehart and Winston.

Akhmad Sudrajat. (2008). Pengertian, pendekatan, strategi, metode, teknik dan model pembelajaran. Bandung: Sinar Baru Algensindo.

Coakes, S.J., \& Steed, L.G. (1996). SPSS for Windows: Analysis without anguish. New York: John Wiley \& Sons.

Cris Zirkle. (2005). Distance education programming barriers in career and technical education in Ohio. The Journal of Vocation Educational Research. Vol. 29, pp. 157-179.

Departemen Tenaga Kerja dan Transmigrasi Daerah Istimewa Yogyakarta. Diakses pada tanggal 21 Juni 2012 dari: http://www. nakertrans.jogjaprov.go.id.

Fernandez, H.J.X. (1984). Testing and Measurement. Jakarta: Depdikbud. 
Hurlock, E.B. (1980). Developmental psychology, a life-span approach (Terjemahan Istiwidayati \& Soedjarwo). New York: McGraw-Hill Inc. (Buku asli diterbitkan 1980).

Isaac, Stephen \& Michael, William B., (1981). Handbook in research and evaluation. California: Edits Publisher.

Lynch, R.L. \& Harnish, D. (1998). Preparing pre-service teachers education students to used work-based strategies to improve instruction. In Contextual teaching and learning: Preparing teachers to enchance student success in the workplace and beyond (pp. 127158). Columbus: OH: ERIC Dearinghouse on Adult, Career, and Vocational Education.

Mifflen, F.J. \& Mifflen, S.C. (1986). Sosiologi Pendidikan. Bandung: Tarsito.

Mohammad Ali, \& Mohammad Asrori. (2009). Psikologi Remaja. Jakarta: PT. Bumi Aksara.

Paul E. Brauchle. (2002) A study of Supervisor and Employee Perseptions of Work Attitudes in Information Age Manufacturing Industries. Journal of
Vocational Education Research. Vol. 6, pp. 124-139.

Sri Suprobo. (2013). Kesiapan kerja siswa SMK Kompetensi Teknik Komputer dan Jaringan. Jurnal Pendidikan Vokasi. Vol. 3 Nomor 3, pp. 347-358.

Sumitro. (1998). Pengantar ilmu pendidikan. IKIP Yogyakarta: UPP IKIP Yogyakarta.

Syamsu Yusuf. (2001). Psikologi perkembangan. Bandung: Penerbit PT. Remaja Rosdakarya.

Thompson, J.F. (1973). Foundations of vocational education, Social and philosophical concepts. New Jersey: Prentice Hall.

Work-Based Learning Guide 2002. Diakses pada tanggal 2 Pebruari 2016, dari: http://www.iowaworkforce.org/files/wl g02.pdf.

Zahrowi Ahmad. (2007). Minat siswa kelas 3 SMP di Kecamatan Piyungan untuk memilih SMK. Tesis Magister, tidak diterbitkan, Universitas Negeri Yogyakarta. 